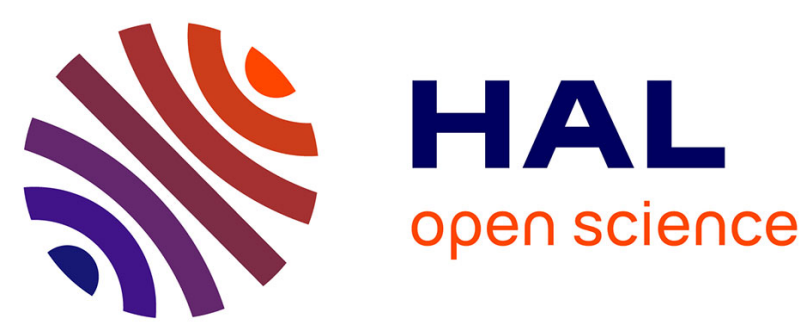

\title{
Development of hormone-dependent prostate cancer models for the evaluation of inhibitors of $17 \beta$-hydroxysteroid dehydrogenase Type 3
}

Joanna M. Day, Helena J. Tutill, Paul A. Foster, Helen V. Bailey, Wesley B. Heaton, Christopher M. Sharland, Nigel Vicker, Barry V.L. Potter, Atul Purohit, Michael J. Reed

\section{To cite this version:}

Joanna M. Day, Helena J. Tutill, Paul A. Foster, Helen V. Bailey, Wesley B. Heaton, et al.. Development of hormone-dependent prostate cancer models for the evaluation of inhibitors of $17 \beta$ hydroxysteroid dehydrogenase Type 3. Molecular and Cellular Endocrinology, 2009, 301 (1-2), pp.251. 10.1016/j.mce.2008.08.014 . hal-00532067

\section{HAL Id: hal-00532067 https://hal.science/hal-00532067}

Submitted on 4 Nov 2010

HAL is a multi-disciplinary open access archive for the deposit and dissemination of scientific research documents, whether they are published or not. The documents may come from teaching and research institutions in France or abroad, or from public or private research centers.
L'archive ouverte pluridisciplinaire HAL, est destinée au dépôt et à la diffusion de documents scientifiques de niveau recherche, publiés ou non, émanant des établissements d'enseignement et de recherche français ou étrangers, des laboratoires publics ou privés. 


\section{Accepted Manuscript}

Title: Development of hormone-dependent prostate cancer models for the evaluation of inhibitors of $17 \beta$-hydroxysteroid dehydrogenase Type 3

Authors: Joanna M. Day, Helena J. Tutill, Paul A. Foster, Helen V. Bailey, Wesley B. Heaton, Christopher M. Sharland,

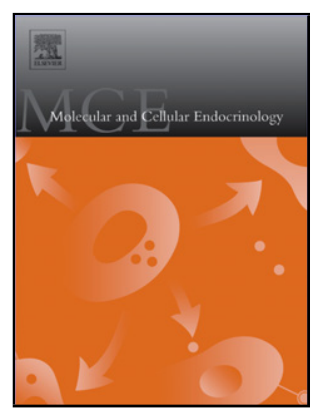
Nigel Vicker, Barry V.L. Potter, Atul Purohit, Michael J. Reed

PII: S0303-7207(08)00367-5

DOI: doi:10.1016/j.mce.2008.08.014

Reference: $\quad$ MCE 6953

To appear in: $\quad$ Molecular and Cellular Endocrinology

Received date: $\quad 26-6-2008$

Revised date: $\quad 12-8-2008$

Accepted date: $\quad$ 13-8-2008

Please cite this article as: Day, J.M., Tutill, H.J., Foster, P.A., Bailey, H.V., Heaton, W.B., Sharland, C.M., Vicker, N., Potter, B.V.L., Purohit, A., Reed, M.J., Development of hormone-dependent prostate cancer models for the evaluation of inhibitors of $17 \beta$ hydroxysteroid dehydrogenase Type 3, Molecular and Cellular Endocrinology (2007), doi:10.1016/j.mce.2008.08.014

This is a PDF file of an unedited manuscript that has been accepted for publication. As a service to our customers we are providing this early version of the manuscript. The manuscript will undergo copyediting, typesetting, and review of the resulting proof before it is published in its final form. Please note that during the production process errors may be discovered which could affect the content, and all legal disclaimers that apply to the journal pertain. 
17 $\beta$-HSD3 inhibition

Development of hormone-dependent prostate cancer models for the evaluation of inhibitors of 17ß-hydroxysteroid dehydrogenase Type 3.

Joanna M. Day ${ }^{\mathrm{a}}$, Helena J. Tutill ${ }^{\mathrm{a}}$, Paul A. Foster ${ }^{\mathrm{a}}$, Helen V. Bailey ${ }^{\mathrm{b}}$, Wesley B. Heaton $^{\mathrm{b}}$, Christopher M. Sharland ${ }^{\mathrm{b}}$, Nigel Vicker ${ }^{\mathrm{b}}$, Barry V. L. Potter ${ }^{\mathrm{b}}$, Atul Purohit ${ }^{\mathrm{a}}$ \& Michael J. Reed ${ }^{\mathrm{a}}$.

${ }^{a}$ Oncology Drug Discovery \& Women's Health Group, Dept. of Endocrinology \& Metabolic Medicine, \& Sterix Ltd., Imperial College London, London W2 1NY, UK.

${ }^{\mathrm{b}}$ Medicinal Chemistry, Dept. of Pharmacy \& Pharmacology, \& Sterix Ltd., University of Bath, Bath BA2 7AY, UK.

Running Title: Inhibition of 17 $\beta$-HSD3.

Keywords: prostate cancer; androgen; testosterone; 17ß-hydroxysteroid dehydrogenase (17 $\beta$-HSD); enzyme inhibition.

This work was supported by Sterix Ltd., a member of the Ipsen Group.

* Corresponding author:

Dr. Joanna M. Day,

Oncology Drug Discovery \& Women’s Health Group,

Department of Endocrinology \& Metabolic Medicine,

$2^{\text {nd }}$ Floor, Mint Wing, Winsland Street,

St Mary’s Hospital, London W2 1NY, UK.

Email: joanna.day@imperial.ac.uk 
17 $\beta$-HSD3 inhibition

\section{ABSTRACT}

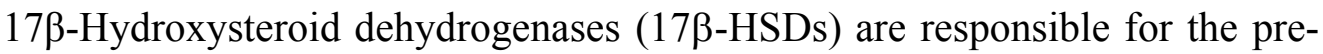
receptor reduction / oxidation of steroids at the 17-position into active / inactive hormones, and the 15 known enzymes vary in their substrate specificity, localisation, and directional activity. 17 $\beta$-HSD Type 3 (17 $\beta$-HSD3) has been seen to be overexpressed in prostate cancer, and catalyses the reduction of androstenedione (Adione) to testosterone $(\mathrm{T})$, which stimulates prostate tumour growth. Specific inhibitors of $17 \beta$-HSD3 may have a role in the treatment of hormone-dependent prostate cancer and benign prostate hyperplasia, and also have potential as male anti-fertility agents.

A 293-EBNA-based cell line with stable expression of transfected human 17 $\beta$ HSD3 was created and used to develop a whole cell radiometric TLC-based assay to assess the $17 \beta$-HSD3 inhibitory potency of a series of compounds. STX2171 \& STX2624 ( IC $_{50}$ values in the $200-450 \mathrm{nM}$ range) were two of several active inhibitors identified. In similar TLC-based assays these compounds were found to be inactive against $17 \beta$-HSD1 and 17 $\beta$-HSD2, indicating selectivity.

A novel proof of concept model was developed to study the efficacy of the compounds in vitro using the androgen receptor positive hormone-dependent prostate cancer cell line, LNCaPwt, and its derivative, LNCaP[17 $\beta-H S D 3]$, transfected and selected for stable expression of $17 \beta-H S D 3$. The proliferation of the parental cell line was most efficiently stimulated by $5 \alpha$-dihydrotestosterone (DHT), but the LNCaP[17 $\beta$-HSD3] cells were equally stimulated by Adione, indicating that $17 \beta-$ HSD3 efficiently converts Adione to T in this model. Adione-stimulated proliferation of LNCaP[17 $\beta$-HSD3] cells was inhibited in the presence of either STX2171 or STX2624. The compounds alone neither stimulated proliferation of the cells nor 
17 $\beta$-HSD3 inhibition

caused significant cell death, indicating that they are non-androgenic with low cytotoxicity. STX2171 inhibited Adione-stimulated growth of xenografts established from LNCaPwt cells in castrated mice in vivo.

In conclusion, a primary screening assay and proof of concept model have been developed to study the efficacy of $17 \beta$-HSD3 inhibitory compounds, which may have a role in the treatment of hormone-dependent cancer. Active compounds are selective for $17 \beta$-HSD3 over $17 \beta$-HSD1 and $17 \beta$-HSD2, non-androgenic with low toxicity, and efficacious in both an in vitro proof of concept model and in an in vivo tumour model. 
17 $\beta$-HSD3 inhibition

\section{INTRODUCTION}

The 17 $\beta$-hydroxysteroid dehydrogenases (17 $\beta$-HSDs) are responsible for the reduction or oxidation of hormones, fatty acids and bile acids in vivo. All require NAD $(\mathrm{P})(\mathrm{H})$ for activity (Shi \& Lin, 2004). Fifteen $17 \beta$-HSDs have been identified to date (Luu-The, Belanger \& Labrie, 2008; Lukacik et al., 2006; Jansson et al., 2006), and with one exception, 17 $\beta$-HSD Type 5 (17 $\beta$-HSD5), an aldo-keto reductase (AKR) (Penning et al., 2000), they are all short chain dehydrogenases / reductases (SDRs) (Peltoketo et al., 1999; Duax et al., 2005; Vikho et al., 2006). The major substrates of the $17 \beta$-HSDs are hormones, and their reduction or oxidation by $17 \beta$-HSDs regulates the amount of active steroid available to bind to a particular receptor. Despite having bidirectional capabilities in vitro, catalysing either the oxidative or reductive reaction in the presence of $\mathrm{NAD}(\mathrm{P})^{+}$or $\mathrm{NAD}(\mathrm{P}) \mathrm{H}$ respectively, in vivo they appear to function unidirectionally (Khan et al., 2004; Luu-The et al., 1995).

$5 \alpha$-Dihydrotestosterone (DHT), formed from testosterone (T) by $5 \alpha$-reductases 1 and 2, is the main intracellular androgen in the prostate and stimulates the growth of hormone-dependent prostate tumours via its interaction with the androgen receptor (AR). 17 $\beta$-HSD3, microsomally expressed almost exclusively in the testes (Geissler et al., 1994; Luu-The et al., 1995), specifically converts non-androgenic androstenedione (Adione) (Laplante \& Poirier, 2007) to active circulating T (Figure 1) in the presence of NADPH. Another 17 $\beta$-HSD, 17 -HSD5 (AKR1C3), can also convert Adione to $\mathrm{T}$, and is expressed more ubiquitously than $17 \beta$-HSD3, having been found in the prostate and in other tissues (Pelletier et al., 1999). However, in vitro it has also been shown to catalyse the reduction of many other substrates, including steroids and prostaglandins, in various positions, including $3 \beta-, 17 \beta-, 20 \alpha-$ 
17 $\beta$-HSD3 inhibition

of steroids, and $11 \alpha-$ and $11 \beta-$ of prostaglandins, forming oestradiol, $20 \alpha-$ progesterone, $9 \alpha, 11 \beta$-prostaglandin $\mathrm{F}_{2}$, and other active compounds (Penning et al., 2000; Komoto et al., 2004). As yet, its major physiological function remains to be determined. The importance of $17 \beta-H S D 3$ in $\mathrm{T}$ production in men is exemplified by the autosomal recessive disorder, male pseudohermaphroditism (Geissler et al., 1994) in which there is a defect in $17 \beta$-HSD3 expression. Affected individuals have a high Adione to $\mathrm{T}$ ratio and are usually reared as females, often having been born with female external genitalia and the absence of a prostate, despite having testes and Wolffian duct-derived male internal genitalia (Andersson \& Moghrabi, 1997).

Although $17 \beta$-HSD3 is expressed almost exclusively in the testes, there have been some reports of its up-regulation in tumours of the prostate, and of its expression in other tissues, such as blood platelets and megakaryocytes (Gnatenko et al., 2005). One report indicated that expression of $17 \beta$-HSD3 mRNA increased over 30 -fold in cancerous prostate biopsies (Koh et al., 2002). The authors noted a corresponding decrease in $17 \beta$-HSD2 mRNA expression, indicating that the reductive formation of T is favoured, but found no change in the expression of 17 $\beta$-HSD5 mRNA. Expression of 17 $\beta$-HSD3 was also up-regulated in an AR-positive prostate cell line, LNCaP, after it was treated for 48 hours with dutasteride (Biancolella et al., 2007), an inhibitor of $5 \alpha$-reductases 1 and 2. A polymorphism in the HSD17B3 gene, G289S, has been linked to an increased susceptibility to prostate cancer (Margiotti et al., 2002).

Treatment of hormone-dependent prostate cancer by androgen ablation is usually initially successful, reducing primary tumour burden and increasing 5 year survival rates. Currently androgen ablation is achieved using various approaches which include orchidectomy, and / or the use of AR blockers such as bicalutamide (Fradet, 2004), luteinising hormone releasing hormone (LHRH) agonists such as 
17 $\beta$-HSD3 inhibition

goserelin (Akaza, 2004), or 5 $\alpha$-reductase inhibitors, such as finasteride and dutasteride (Tindall \& Rittmaster, 2008). However, the use of some of the more radical treatments, such as orchidectomy and LHRH agonists, can result in undesirable adverse effects on quality of life, including loss of sexual interest and function and bone mineral density.

Despite the success of these early stage treatments, prostate cancer is the third highest cause of male cancer-related death as tumours are often unnoticed for several years, presenting at an advanced, apparently androgen-independent, stage in older men. However, many studies now indicate that the majority of advanced prostate cancers may not be independent of androgen signalling. Instead tumours have developed apparent independence via mechanisms such as AR up-regulation, an adaptation to the low levels of androgen present during ablation therapy, or mutations to the pathways involved in the activation of the AR, such as mutations in the receptor itself, or in its co-regulators, allowing enhanced activation by the low level androgens (Mizokami et al., 2004) or ligands other than androgens to activate the proliferative pathways (Rau et al., 2005; Pienta \& Bradley, 2006). High levels of T and DHT have been found in the prostate of patients with recurrence during ablation therapy, suggesting that surgical or chemical castration treatments may not completely remove active androgens, and that in situ formation of $\mathrm{T}$ from adrenal androgen production may continue (Titus et al., 2005).

A decrease in the formation of $\mathrm{T}$ by the inhibition of 17 $\beta$-HSD3 should provide an effective treatment for hormone-dependent prostate cancer. Because of the enzyme's unique expression profile and substrate specificity, use of 17ß-HSD3 inhibitors may result in fewer side effects than other hormonal treatments, such as orchidectomy, or LHRH inhibitors which act upstream of the 17 $\beta$-HSD3 reaction and 
17 $\beta$-HSD3 inhibition

affect the systemic balance of other hormones, not just the conversion of Adione to $\mathrm{T}$. The inhibitors should be similarly effective in the treatment of benign prostate hyperplasia and may also have a role as male anti-fertility agents. This report describes the identification and characterisation of two novel 17 $\beta$-HSD3 inhibitors, and the development of in vitro and in vivo models to investigate their efficacy as therapies for androgen-dependent prostate cancer. 
17 $\beta$-HSD3 inhibition

MATERIALS \& METHODS

\section{Candidate 17 $\beta$-HSD3 inhibitor compounds}

The syntheses of the candidate $17 \beta-\mathrm{HSD} 3$ inhibitor compounds have been reported (Vicker et al., 2007). All compounds exhibited spectroscopic and analytical data in accordance with their structure. Their purity ( $>95 \%)$ was confirmed by high performance liquid chromatography analysis. A compound previously identified by Bristol Myers Squibb (BMS) as a potential 17 $\beta$-HSD3 inhibitor (DBT 1; Fink et al., 2006), was synthesised using a modified published method (Yale et al., 1972).

\section{Cell culture}

LNCaP cells (LGC Promochem, Teddington, UK) were cultured in RPMI1640 medium (Sigma Aldrich Company Ltd., Poole, UK) supplemented by 10\% foetal bovine serum (FBS), $2 \mathrm{mM}$ L-glutamine, $2 \mathrm{mM}$ sodium pyruvate, $1 \%$ nonessential amino acids and $0.075 \%$ sodium bicarbonate (all from Sigma Aldrich Company Ltd.). 293-EBNA cells (Invitrogen Ltd., Paisley, UK) were maintained in Dulbecco's modified Eagle's medium (Sigma Aldrich Company Ltd.) containing 10\% FBS, 2 mM L-glutamine, 0.075\% sodium bicarbonate, and $250 \mu \mathrm{g} / \mathrm{ml} \mathrm{G418} \mathrm{(Sigma}$ Aldrich Company Ltd.). All cells were maintained at $37^{\circ} \mathrm{C}$ in a humidified atmosphere at $5 \% \mathrm{CO}_{2}$.

\section{Cloning}

The complete 17 $\beta$-HSD3 (IMAGE) cDNA sequence was cloned into the pCEP4 expression vector (Invitrogen) to form pCEP4.17 $\beta$-HSD3 for expression in 
17 $\beta$-HSD3 inhibition

mammalian cells. The construct was sequenced to confirm correct insertion of the cDNA into the vector.

\section{Expression of 17 $\beta$-HSD3 cDNA}

293-EBNA and LNCaP cells were transfected with $1 \mu \mathrm{g}$ pCEP4.17 $\beta$-HSD3 or vector alone in 6 well plates at 50-70\% confluency using a 1:3 (w/v) DNA:FuGENE 6 transfection reagent ratio (Roche Diagnostics, Burgess Hill, UK). After 48 hours cDNA expression was analysed by RT-PCR and Adione to T activity assays. Transfected cells were selected for stable expression of the plasmids over several weeks by the addition of $250 \mu \mathrm{g} / \mathrm{ml}$ Hygromycin B (Invitrogen) to the growth medium.

\section{RT-PCR analysis}

mRNA was purified from T75 flasks or 6 well plates at approximately $80 \%$ confluency using RNeasy and QIAshredder kits (QIAGEN, Crawley, UK) and stored at $-80^{\circ} \mathrm{C}$. A $5 \mu \mathrm{g}$ aliquot of each mRNA sample was reverse transcribed in a final volume of $33 \mu \mathrm{l}$ to form cDNA using the 'First-Strand cDNA Synthesis Kit' (GE Healthcare, Amersham, UK) and stored at $-20^{\circ} \mathrm{C}$. RT-PCR reactions were performed in a 'Rotor Gene 2000 Real-Time Cycler' (Corbett Life Science, Cambridge, UK) with $0.5 \mu 1 \mathrm{cDNA}$ in a final volume of $10 \mu \mathrm{l}$, using Taqman universal PCR master mix and Taqman expression assays containing primers and probes for $17 \beta$-HSD3, and for the endogenous control gene, RPLO (Applied Biosystems, Warrington, UK). The conditions were as follows: $95^{\circ} \mathrm{C}$ for 10 minutes; followed by 40 cycles of $95^{\circ} \mathrm{C}$ for 15 seconds, and $60^{\circ} \mathrm{C}$ for 60 seconds. Relative mRNA expression was calculated using 
17 $\beta$-HSD3 inhibition

the comparative quantitation algorithm in the Rotor Gene 6 software (Corbett Life Science).

\section{7 $\beta$-HSD3 activity assay}

Cells at $\sim 80 \%$ confluency were incubated with $2-3 \mathrm{nM}^{3} \mathrm{H}$-Adione $(65.0 \mathrm{Ci}$ / mmol; Perkin Elmer, Boston, MA) in 24 well tissue culture plates. For inhibitor screening assays, 293-EBNA[HSD3] cells were plated at 50,000 cells/well 48 hours pre-assay in medium free of the antibiotics G418 or Hygromycin B and at assay the substrate was added in the presence or absence of candidate 17 $\beta$-HSD3 inhibitors. Blank incubations were carried out in parallel by incubating labelled steroid in cellfree wells. After incubation of the substrate $\left(+/-\right.$ inhibitor) at $37^{\circ} \mathrm{C}$ for 2 hours, the steroids were isolated from the mixture by extraction with diethyl ether in the presence of ${ }^{14} \mathrm{C}-\mathrm{T}$ (5000 dpm; Perkin Elmer) to monitor procedural losses and $25 \mu \mathrm{g}$ of unlabelled $\mathrm{T}$ for product identification after thin layer chromatography (TLC). Separation of ${ }^{3} \mathrm{H}-\mathrm{T}$ from ${ }^{3} \mathrm{H}$-Adione was achieved by TLC using a dichloromethane : ethyl acetate (DCM:EtOAc) 4:1 v/v solvent mix, and the production of ${ }^{3} \mathrm{H}-\mathrm{T}$ was calculated from the ${ }^{3} \mathrm{H}$ counts detected and recovery of ${ }^{14} \mathrm{C}-\mathrm{T}$ (Beckman LS 6000SC; Beckman Coulter UK Ltd., High Wycombe, UK).

\section{7 $\beta$-HSD 1 activity assay}

T47D human breast cancer cells in 24 well tissue culture plates were incubated with $2 \mathrm{nM}{ }^{3} \mathrm{H}$-oestrone (E1; 65.0 Ci / mmol; Perkin Elmer) in the presence or absence of $10 \mu \mathrm{M}$ candidate $17 \beta$-HSD3 inhibitor. After 30 minutes at $37^{\circ} \mathrm{C}$, the steroids were isolated from the mixture by extraction with diethyl ether, using ${ }^{14} \mathrm{C}$-oestradiol (E2; 5000 dpm; Perkin Elmer) to monitor procedural losses. Separation of ${ }^{3} \mathrm{H}-\mathrm{E} 2$ from ${ }^{3} \mathrm{H}-$ 
17 $\beta$-HSD3 inhibition

E1 was achieved using TLC in DCM:EtOAc 4:1 v/v solvent, and the production of ${ }^{3} \mathrm{H}$-E2 was calculated from the ${ }^{3} \mathrm{H}$ counts detected and recovery of ${ }^{14} \mathrm{C}-\mathrm{E} 2$ (Beckman LS 6000SC).

\section{7 $\beta$-HSD2 activity assay}

MDA-MB-231 human breast cancer cells in T25 flasks were incubated with 2 nM ${ }^{3} \mathrm{H}-\mathrm{E} 2(41.3 \mathrm{Ci} / \mathrm{mmol}$; Perkin Elmer) in the presence or absence of $10 \mu \mathrm{M}$ candidate $17 \beta$-HSD3 inhibitors. After 3 hours at $37^{\circ} \mathrm{C}$, the steroids were isolated from the mixture by extraction with diethyl ether, using ${ }^{14} \mathrm{C}-\mathrm{E} 1$ (5000 dpm; Perkin Elmer) to monitor procedural losses. Separation of ${ }^{3} \mathrm{H}-\mathrm{E} 1$ from ${ }^{3} \mathrm{H}-\mathrm{E} 2$ was achieved using TLC (DCM:EtOAc, 4:1 v/v) and the amount of ${ }^{3} \mathrm{H}-\mathrm{E} 1$ produced was calculated from the ${ }^{3} \mathrm{H}$ counts detected and recovery of ${ }^{14} \mathrm{C}$-E1 (Beckman LS 6000SC).

\section{In vitro Adione-stimulated model}

LNCaPwt or LNCaP[HSD3] cells were seeded in a 24 well plate at 40,000 cells/well in 10\% FBS growth medium (Day 1). On Day 4 the cells were washed with phosphate buffered saline (PBS) and the medium was replaced with $0.1 \%$ FBS growth medium. The cells were treated on Day 6 with $10 \mathrm{nM}$ of either the appropriate steroid(s) or hydroxyflutamide in the presence or absence of 17ß-HSD3 inhibitor or vehicle (100\% methanol) in $0.1 \%$ FBS growth medium, and cultured for a further 15 days with the medium and treatments renewed every 48-72 hours. On Day 19-21 the cells were counted using a Coulter cell counter (Beckman Coulter UK Ltd.).

\section{In vivo inhibition of Adione-stimulated LNCaP tumour proliferation in castrated mice}


17 $\beta$-HSD3 inhibition

All animals received food and water ad libitum and were maintained in positive pressure isolators under a 12 hour light-dark cycle. The experiments were approved by the Imperial College London ethical review committee.

Castrated male MF-1 nude mice (Harlan UK Ltd., Bicester, UK) were inoculated s.c. with $1 \times 10^{7}$ LNCaPwt cells in $50 \mu$ l Matrigel (BD Biosciences, Bedford, MA) into one flank of each mouse. LNCaPwt tumour growth was stimulated using $100 \mu \mathrm{g}$ (s.c.) Adione in 10\% ethanol / 90\% propylene glycol (PG) per mouse per day. When the tumours were $50-100 \mathrm{~mm}^{3}$, animals were treated additionally with $25 \mathrm{mg} / \mathrm{kg}$ /day STX2171 or vehicle (5\% THF / 95\% PG) in a combined s.c. injection with Adione. Every seven days tumour measurements were recorded using electronic callipers and the mice were weighed. Tumour volume was calculated using the formula: volume $=\left(\right.$ length $x$ width $\left.{ }^{2}\right) / 2$. At the end of the studies the mice were culled, and final body weights and tumour sizes were determined.

\section{Statistical analysis}

Student's $t$-test was used to determine the significance of differences in in vivo data. All values are represented as mean $+/-$ s.d. 
17 $\beta$-HSD3 inhibition

\section{RESULTS}

\section{Screening of candidate inhibitors}

\section{Screening assay development}

RT-PCR analysis indicated that the expression of $17 \beta-\mathrm{HSD} 1,2,3 \& 5 \mathrm{mRNA}$ in 293-EBNA cells (Invitrogen) is negligible (results not shown). However, 48 hours after transfection with pCEP4.17 $\beta$-HSD3, there was a high level of expression of $17 \beta-$ HSD3 mRNA in the 293-EBNA cells. This expression level was maintained after Hygromycin B (Invitrogen) selection of the transfected cells, resulting in 293EBNA[HSD3], a cell line with stable expression of 17 $\beta$-HSD3 (Figure 2a).

The 293-EBNA[HSD3] cell line was used to develop a whole cell radiometric assay for Adione to $\mathrm{T}$ activity and inhibition (detailed in the Materials and Methods section of this paper). The TLC-based assay uses physiologically relevant levels of ${ }^{3} \mathrm{H}$-Adione as substrate, at $2-3 \mathrm{nM}$, and assay sensitivity is maintained by the addition of a known amount of ${ }^{14} \mathrm{C}-\mathrm{T}$ to monitor procedural losses. When measuring the activity of $\sim 200,000$ cells / well of a 24 well plate, the optimal duration of the assay was found to be 2 hours, as at this time point there was efficient conversion of substrate without the reaction being saturated. Assay of wild type or mock-transfected 293-EBNA cells resulted in negligible activity in this assay (Figure 2b).

Assay of candidate 17 $\beta$-HSD3 inhibitors

A series of approximately 50 candidate $17 \beta$-HSD3 inhibitor compounds was tested in the assay. The inhibitory $\mathrm{IC}_{50}$ value, the concentration at which the reaction is $50 \%$ inhibited, was determined for those with $>70 \%$ activity at $10 \mu \mathrm{M}$. STX 2171 
17 $\beta$-HSD3 inhibition

and STX2624 (Figure 3), with $\mathrm{IC}_{50}$ values in the 200-450 nM range, were two of several active inhibitors identified (Vicker et al., 2007). These activities were comparable to that of a dibenzothiazocine compound DBT 1 (STX2622; Figure 3), previously identified by BMS as a potential 17ß-HSD3 inhibitor (Fink et al., 2006).

In similar whole cell radiometric TLC-based assays (Day et al., 2006a), STX2171 and STX2624 had negligible activity against the oxidative 17 $\beta$-HSD2 enzyme which catalyses the reverse reaction, $\mathrm{T}$ to Adione (inhibiting 17 $\beta$-HSD2 activity at $10 \mu \mathrm{M}$ by $20.3+/-3.5 \%$ and $18.9+/-2.9 \%$, respectively). STX2171 was also shown to be inactive in the inhibition of $17 \beta$-HSD1, the enzyme that catalyses the reduction of the inactive oestrogen, oestrone, to active oestradiol $(1.7+/-2.6 \%$ inhibition at $10 \mu \mathrm{M})$.

\section{In vitro proof of concept model}

A model was developed to investigate whether candidate $17 \beta$-HSD3 inhibitors can block Adione-stimulated proliferation of 17 $\beta$-HSD3-expressing AR-positive prostate cancer cells.

\section{Preparation of an appropriate cell line}

To establish whether LNCaP cells would be suitable for use in this model, the mRNA levels of steroid metabolising enzymes in LNCaPwt cells were investigated by RT-PCR. Of those enzymes tested, which included steroid sulphatase (STS), aromatase, and 17 $\beta$-HSD Types 1, 2, 3, 5 and 12, the cells were found to have some expression of STS, high expression of $17 \beta$-HSD12, but negligible expression of $17 \beta$ HSD Types 1, 2, 3 and 5 (Figure 4a). Despite their lack of naturally expressed $17 \beta$ HSD3, they were suitable for use in the proof of concept model as they could be 
17 $\beta$-HSD3 inhibition

transfected with $17 \beta$-HSD3 to create a stable cell line which converted Adione to T without interference from other steroid converting enzymes such as aromatase, which would convert the Adione substrate to oestrone, or other $17 \beta$-HSDs, such as the reductive 17 $\beta$-HSDs 1 and 5, and the oxidative 17 $\beta$-HSD2.

An LNCaPwt-derived cell line with stable expression of 17 $\beta$-HSD3, LNCaP[HSD3], was established by pCEP4.17 $\beta$-HSD3 cDNA transfection and selection with Hygromycin B over several weeks. Both 17 $\beta$-HSD3 mRNA expression (Figure 4b) and Adione to T activity levels (Figure 4c) of the LNCaP[HSD3] cell line were comparable to those of the 293-EBNA[HSD3] cells.

Development of the in vitro proof of concept model

The LNCaPwt cell line was used to establish the optimal conditions for androgen-dependent stimulation of LNCaP-derived cells. The cells were plated in 24 well plates at low density, and allowed to adhere for 3 days before the FBS content of the medium was reduced from $10 \%$ to $0.1 \%$. After 48 hours the cells were cultured in the presence of varying concentrations of $\mathrm{T}$, from $1 \mathrm{nM}$ to $1 \mu \mathrm{M}$, and maintained without passage, with medium and supplements replaced every 3-4 days, until the wells at highest density were approaching confluency ( $\sim 13-15$ days). A concentration of $10 \mathrm{nM}$ T was found to be optimal for stimulation (results not shown), so this dose was used for all following experiments.

The assay was repeated using $10 \mathrm{nM}$ Adione or $10 \mathrm{nM}$ DHT to stimulate growth. As seen with $10 \mathrm{nM} \mathrm{T,} \mathrm{DHT} \mathrm{also} \mathrm{effectively} \mathrm{stimulated} \mathrm{proliferation} \mathrm{of} \mathrm{the}$ cells, whereas $10 \mathrm{nM}$ Adione resulted in only $50 \%$ of the stimulation seen with DHT (Figure 4d). However, in LNCaP[HSD3] cells, $10 \mathrm{nM}$ Adione, $\mathrm{T}$ or DHT all efficiently stimulated proliferation (Figure 4e) indicating that in this model the $17 \beta$ - 
17 $\beta$-HSD3 inhibition

HSD3 expressed by the cells actively converts all available Adione to T. In both cell lines the positive control, $1 \mu \mathrm{M}$ hydroxyflutamide, most efficiently stimulates cell proliferation to $150 \%$ that of $10 \mathrm{nM}$ DHT (Figures $4 \mathrm{~d} \& \mathrm{e}$ ).

Assay of lead inhibitors in the in vitro proof of concept model

Using the LNCaP[HSD3] cell line, the two lead compounds, STX2171 and STX2624, were tested at $5 \mu \mathrm{M}$ in the in vitro proof of concept model against the BMS positive control inhibitor, STX2622 (Figure 5a). Cell proliferation was efficiently stimulated by $10 \mathrm{nM}$ Adione, to $550 \%$ of the number in $0.1 \%$ FBS medium alone. In the presence of $5 \mu \mathrm{M}$ STX2171 and STX2624, Adione-stimulated proliferation was inhibited by $99 \%$ and $66 \%$ respectively. STX2622 did not inhibit this stimulation (98\% of Adione-stimulated cell number). None of the compounds stimulated proliferation of the cells in the absence of Adione, indicating that they are nonandrogenic. However, in the absence of Adione, STX2171 decreased the number of non-stimulated cells to $5 \%$, indicating that it is cytotoxic at this dose.

The assay was repeated, using a lower $500 \mathrm{nM}$ dose of STX2171, and STX2624 at both $5 \mu \mathrm{M}$ and $500 \mathrm{nM}$ (Figure 5b). Again $10 \mathrm{nM}$ Adione efficiently stimulated proliferation of the LNCaP[HSD3] cells, to $1200 \%$ of non-stimulated cell number. At $500 \mathrm{nM}$, STX2171 efficiently inhibited Adione-stimulated proliferation by $74 \%$ without causing toxicity in the non-stimulated wells. STX2624 was also efficacious in this model, inhibiting Adione-stimulation by $79 \%$ at $5 \mu \mathrm{M}$, and by $52 \%$ at $500 \mathrm{nM}$, with no indication of androgenicity and little indication of toxicity in the absence of Adione.

To confirm that the effect of $500 \mathrm{nM}$ STX2171 is due to the inhibition of Adione to $\mathrm{T}$ conversion, proliferation of $\mathrm{LNCaPwt}$ cells was stimulated by $10 \mathrm{nM}$ 
17 $\beta$-HSD3 inhibition

Adione, T, or DHT, or by $1 \mu \mathrm{M}$ hydroxyflutamide, in the presence or absence of 500 nM STX2171 (Figure 5c). STX2171 had little effect on the cell numbers after T, DHT, or hydroxyflutamide stimulation, or after culture in $10 \%$ FBS medium, but fully inhibited stimulation by $10 \mathrm{nM}$ Adione.

\section{In vivo anti-tumour activity of STX2171}

Single LNCaPwt xenografts were established in one flank of castrated male MF-1 mice. Mice were dosed s.c. with $100 \mu \mathrm{g}$ Adione per day until the tumours became visible, when they were then dosed additionally with either vehicle (5\% THF / 95\% PG) or $25 \mathrm{mg} / \mathrm{kg}$ STX2171. Control tumours treated with vehicle plus Adione continued to grow, to $380 \%$ of the volume at the start of dosing, whereas the growth of those dosed with STX2171 was significantly inhibited by $81 \%$ in comparison to control ( $p<0.05$; Figure 6 ), the tumours growing to only $157 \%$ of the volume at the start of dosing. Mouse body weight was unaffected by either Adione or STX2171 treatment. 
17 $\beta$-HSD3 inhibition

\section{DISCUSSION}

Despite the success of inhibitors of steroidogenic enzymes in the clinic, such as those of aromatase and steroid sulphatase, the development of inhibitors of $17 \beta$ HSDs is at a relatively early stage (Day et al., 2008a; Poirier, 2003; Penning, 1996). At present, none of these inhibitors has reached clinical trial, and only recently has efficacy been demonstrated in vivo for the first of the enzymes, 17 $\beta$-HSD1, in models of breast cancer (Day et al., 2006b; Husen et al., 2006; Day et al., 2008b).

$17 \beta$-HSD3 catalyses the reduction of Adione to form T, further metabolised by $5 \alpha$-reductases $1 \& 2$ to DHT which stimulates the growth of hormone-dependent prostate tumours. This report describes the identification of two novel 17 $\beta$-HSD3 inhibitors, and the development of in vitro and in vivo models to investigate their efficacy as therapies for androgen-dependent prostate cancer.

293-EBNA cells were transfected with $17 \beta$-HSD3 and those with stable expression of the cDNA were selected for use in the development of a whole cell radiometric assay for Adione to T activity and inhibition. Using this assay, STX2171 and STX2624, with $\mathrm{IC}_{50}$ values of less than $500 \mathrm{nM}$, were identified from a panel of around 50 compounds. These activities were comparable to that of a dibenzothiazocine compound, DBT 1 (STX2622), published by BMS (Fink et al., 2006). The screening assay was set up as a whole cell assay, rather than using the purified enzyme, so that the resulting $\mathrm{IC}_{50}$ value for each compound was a measure of both its $17 \beta$-HSD3 inhibitory activity, as well as its ability to penetrate the cell, a property necessary for its therapeutic use. Another property that a successful $17 \beta$ HSD3 inhibitor requires is a lack of inhibition of $17 \beta$-HSD2, as this catalyses the opposite reaction to that of $17 \beta-\mathrm{HSD} 3$, the oxidation of active $\mathrm{T}$ to inactive Adione. 
17 $\beta$-HSD3 inhibition

Both of these compounds were selective for $17 \beta$-HSD3 inhibition, causing $<20 \%$ inhibition of $17 \beta$-HSD2 activity at $10 \mu \mathrm{M}$. STX2171 was also tested at $10 \mu \mathrm{M}$ against the $17 \beta$-HSD1 enzyme, which forms active oestradiol from oestrone, and was found to be inactive.

Having established that these two compounds were effective and selective inhibitors of $17 \beta-H S D 3$, a proof of concept model was developed to study whether this inhibitory activity would be of benefit in the treatment of hormone-dependent cancer. This model was initially established in vitro, with a view to transferring it into the in vivo setting once optimised. LNCaP prostate cancer cells were investigated for use in this model as they are androgen receptor positive, respond to androgenic stimulation, and grow as xenografts in mice (Horoszewicz et al., 1983).

RT-PCR analysis of LNCaP mRNA indicated that the wild type cells (LNCaPwt) have negligible expression of the steroidogenic enzymes $17 \beta$-HSD1, 2, 3 and 5, and aromatase, some expression of STS, and a high level of expression of $17 \beta$ HSD12. As the expression of $17 \beta$-HSD3 is negligible in this cell line, the cells were transfected with 17 $\beta$-HSD3 cDNA, and a cell line (LNCaP[HSD3]) with stable expression of the enzyme was derived for use in the model. The expression of $17 \beta$ HSD12 and STS should not interfere in the use of this cell line for the 17 $\beta$-HSD3 model. $17 \beta-H S D 12$, in addition to $17 \beta-H S D 1$, has been reported to catalyse the reduction of oestrone to oestradiol (Luu-The, Tremblay \& Labrie, 2006), but work from this laboratory has shown that it is unable to mediate this reaction (Day et al., 2008b). Instead it is thought to be involved in the metabolism of fatty acids (Moon \& Horton, 2003). STS, however, is involved in steroidogenesis, but as it acts to activate steroid sulphates by hydrolysis of their sulphate groups (Stanway et al., 2006), its activity will not affect the study of the effects of $17 \beta-$ HSD3 inhibition in this model. 
17ß-HSD3 inhibition

Conditions for the proof of concept model were optimised using the LNCaPwt cell line. In experiments to monitor hormone-dependent cell proliferation in vitro, cells are often grown in medium containing charcoal-stripped FBS as this removes any steroids usually present in FBS (Macdiarmid et al., 1994). However, as the LNCaP cells were not viable in this medium without supplementation for the duration required for this assay, but were viable without proliferation in medium containing $0.1 \%$ FBS, $0.1 \%$ FBS-containing medium was used as the basal medium for steroid stimulation assays.

Proliferation of both LNCaPwt and LNCaP[HSD3] cells was efficiently stimulated by the addition of $10 \mathrm{nM}$ T or DHT to the basal medium. Despite being an AR antagonist, hydroxyflutamide also efficiently stimulated the growth of both cell lines. This effect is well-documented in LNCaP cells, as they express a mutated AR which is stimulated by some anti-androgens (Veldscholte et al., 1992). Hydroxyflutamide was therefore used as a positive control in all LNCaPwt and LNCaP[HSD3] steroid stimulation assays. Although $10 \mathrm{nM}$ Adione caused some stimulation of proliferation in the LNCaPwt cells, the expression of $17 \beta-\mathrm{HSD} 3$ caused this to increase in the LNCaP[HSD3] cells to the same level seen for $\mathrm{T}$ or DHT, indicating that the enzyme was functioning efficiently in this model.

STX2171 caused cell cytoxicity at $5 \mu \mathrm{M}$, but both STX2171 and STX2624 inhibited Adione-stimulated proliferation of LNCaP[HSD3] cells at $500 \mathrm{nM}$ without noticeable toxicity, STX2171 being most efficacious. A dibenzothiazocine compound, STX2622, previously identified by BMS as a potential 17 $\beta$-HSD3 inhibitor (DBT 1; Fink et al., 2006), however, failed to inhibit the stimulation by Adione, even at $5 \mu \mathrm{M}$, despite having a similar $\mathrm{IC}_{50}$ for $17 \beta$-HSD3 inhibition to STX2171 and STX2624 in the whole cell assay. It is possible that this may be due to the either the stability of 
17 $\beta$-HSD3 inhibition

this compound in this longer term assay, or to its effects on other enzymes as its selectivity over $17 \beta$-HSD1 and 17 $\beta$-HSD2 inhibition has not been determined. None of the three compounds tested caused any stimulation of growth in the absence of Adione, indicating that the compounds were not themselves androgenic.

Further evidence of the specificity of the inhibitory effect of STX2171 for 17 $\beta$-HSD3-dependent Adione conversion was obtained in a similar study using LNCaPwt cells, in which cells were grown in either $0.1 \%$ or $10 \%$ FBS medium, or in $0.1 \%$ FBS medium and stimulated by Adione, T, DHT or hydroxyflutamide. Only Adione-stimulated growth was inhibited by STX2171, indicating that STX2171 does not have antagonistic effects on the AR, and that it is not cytotoxic at this dose.

In a preliminary model, LNCaPwt xenografts were established in castrated mice supplemented with $100 \mu \mathrm{g}$ Adione (s.c.) / day. After two weeks of dosing at 25 $\mathrm{mg} / \mathrm{kg} /$ day (s.c.), in comparison to vehicle-treated animals, STX2171 efficiently inhibited the growth of these tumours by $81 \%$. Despite the fact that several groups are now working on inhibitors of 17ß-HSD3 (Bérubé \& Poirier, 2007; Fink et al., 2006; Lota et al., 2006; Tchédam Ngatcha et al., 2005; Le Lain et al., 2002; Maltais, LuuThe \& Poirier, 2002), this is the first published report of anti-tumour activity of a $17 \beta-$ HSD3 inhibitor in an in vivo model. However, this is a preliminary model and thus has limitations, despite its demonstration of STX2171 bioavailability and anti-tumour activity. In this report we have demonstrated that the wild type cells in vitro are stimulated to some extent by Adione, despite their low level of expression of $17 \beta$ HSD3, and that this stimulation is inhibited by STX2171. This indicates that the inhibition of tumour growth in vivo may also be due to inhibition of the minimal levels of $17 \beta$-HSD3 expressed by these tumours. To determine whether the in vivo activity is entirely a result of $17 \beta-H S D 3$ inhibition, whether STX2171 also has any 
17 $\beta$-HSD3 inhibition

cytotoxic effect on the tumours, or whether 17 $\beta$-HSD5 activity could be involved in Adione to $\mathrm{T}$ conversion in these tumours, the model requires further refinement. Initially, the preferred model for future studies would be the use of xenografts formed from inoculation of the mice with LNCaP[HSD3] cells, developed for use in the in vitro studies reported in this paper. Plasma testosterone concentrations, as well as tumour volume, should be determined in non-stimulated, Adione-stimulated, and STX2171-inhibited groups. The efficacy of STX2171 in castrated and intact mice will also be explored. These LNCaP[HSD3] xenograft studies are presently on-going.

In conclusion, a primary screening assay and proof of concept model have been developed to study the efficacy of $17 \beta$-HSD3 inhibitory compounds. Active compounds are selective for $17 \beta$-HSD3 over other 17 $\beta$-HSD enzymes, nonandrogenic with low toxicity, and efficacious in the in vitro proof of concept model. The lead compound, STX2171, has anti-tumour activity in an in vivo hormonedependent prostate cancer model. These models provide evidence that $17 \beta$-HSD3 inhibitory compounds may have application in the treatment of hormone-dependent prostate cancer. 
17 $\beta$-HSD3 inhibition

\section{ACKNOWLEDGEMENTS}

This work was supported by Sterix Ltd., part of the Ipsen Group. 
17 $\beta$-HSD3 inhibition

\section{REFERENCES}

Akaza, H., 2004. Adjuvant goserelin improves clinical disease-free survival and reduces disease-related mortality in patients with locally advanced or localized prostate cancer. Brit. J. Urol. Int. 93, 42-46.

Andersson, S., Moghrabi, N., 1997. Physiology and molecular genetics of 17ßhydroxysteroid dehydrogenases. Steroids 62, 143-147.

Bérubé, M., Poirier, D., 2007. Chemical synthesis and in vitro biological evaluation of a phosphorylated bisubstrate inhibitor of type 3 17ß-hydroxysteroid dehydrogenase. J. Enzyme Inhib. Med. Chem. 22, 201-211.

Biancolella, M., Valentini, A., Minella, D., Vecchione, L., D'Amico, F., Chillemi, G., Gravina, P., Bueno, S., Prosperini, G., Desideri, A., Federici, G., Bernardini, S., Novelli, G., 2007. Effects of dutasteride on the expression of genes related to androgen metabolism and related pathway in human prostate cancer cell lines. Invest. New Drugs 25, 491-497.

Day, J.M., Tutill, H.J., Newman, S.P., Purohit, A., Lawrence, H.R., Vicker, N., Potter, B.V.L., Reed, M.J., 2006a. 17ß-Hydroxysteroid dehydrogenase Type 1 and Type 2: Association between mRNA expression and activity in cell lines. Mol. Cell. Endocrinol. 248, 246-249.

Day, J.M., Foster. P.A., Chander, S.K., Tutill, H.J., Parsons, M.F.C., Allan, G.M., Lawrence, H.R., Vicker, N., Potter, B.V.L., Reed, M.J., Purohit, A., 2006b. Inhibition of estrone-dependent tumor growth in vivo by the 17ß-HSD1 inhibitor, 2-ethyl-16ß-m-pyridylmethylamidomethyl-estrone (2-EtE1-F). Breast Cancer Res. Treat. 100, S197. 
17ß-HSD3 inhibition

Day, J.M., Tutill, H.J., Purohit, A., Reed, M.J., 2008a. Design and validation of specific inhibitors of 17ß-hydroxysteroid dehydrogenases for therapeutic application in breast and prostate cancer, and in endometriosis. Endocr. Relat. Cancer (In press).

Day, J.M., Foster, P.A., Tutill, H.J., Parsons, M.F.C., Newman, S.P., Chander, S.K., Allan, G.M., Lawrence, H.R., Vicker, N., Potter, B.V.L., Reed, M.J., Purohit, A., 2008b. 17 $\beta$-Hydroxysteroid dehydrogenase Type 1 , and not Type 12 , is a target for endocrine therapy of hormone-dependent breast cancer. Int. J. Cancer 122, 1931-1940.

Duax, W.L., Thomas, J., Pletnev, V., Addlagatta, A., Huether, R., Habegger, L., Weeks, C.M., 2005. Determining structure and function of steroid dehydrogenase enzymes by sequence analysis, homology modeling, and rational mutational analysis. Ann. N. Y. Acad. Sci. 1061, 135-148.

Fink, B.E., Gavai, A.V., Tokarski, J.S., Goyal, B., Misra, R., Xiao, H.Y., Kimball, S.D., Han, W.C., Norris, D., Spires, T.E., You, D., Gottardis, M.M., Lorenzi, M.V., Vite, G.D., 2006. Identification of a novel series of tetrahydrodibenzazocines as inhibitors of $17 \beta$-hydroxysteroid dehydrogenase type 3. Bioorg. Med. Chem. Lett. 16, 1532-1536.

Fradet, Y., 2004. Bicalutamide (Casodex) in the treatment of prostate cancer. Expert Rev. Anticancer Ther. 4, 37-48.

Geissler, W.M., Davis, D.L., Wu, L., Bradshaw, K.D., Patel, S., Mendonca, B.B., Elliston, K.O., Wilson, J.D., Russell, D.W., Andersson, S., 1994. Male pseudohermaphroditism caused by mutations of testicular 17ß-hydroxysteroid dehydrogenase 3. Nat. Genet. 7, 34-39. 
17 $\beta$-HSD3 inhibition

Gnatenko, D.V., Cupit, L.D., Huang, E.C., Dhundale, A., Perrotta, P.L., Bahou, W.F., 2005. Platelets express steroidogenic 17ß-hydroxysteroid dehydrogenases:

Distinct profiles predict the essential thrombocythemic phenotype. Thromb. Haemost. 94, 412-421.

Horoszewicz, J.S., Leong, S.S., Kawinski, E., Karr, J.P., Rosenthal, H., Chu, T.M., Mirand, E.A., Murphy, G.P., 1983. LNCaP model of human prostatic carcinoma. Cancer Res. 43, 1809-1818.

Husen, B., Huhtinen, K., Poutanen, M., Kangas, L., Messinger, J., Thole, H., 2006. Evaluation of inhibitors for $17 \beta$-hydroxysteroid dehydrogenase type 1 in vivo in immunodeficient mice inoculated with MCF-7 cells stably expressing the recombinant human enzyme. Mol. Cell. Endocrinol. 248, 109-113.

Jansson, A.K., Gunnarsson, C., Cohen, M., Sivik, T., Stål, O., 2006. 17ßhydroxysteroid dehydrogenase 14 affects estradiol levels in breast cancer cells and is a prognostic marker in estrogen receptor-positive breast cancer. Cancer Res. 66, 11471-11477.

Khan, N., Sharma, K.K., Andersson, S., Auchus, R.J., 2004. Human 17ßhydroxysteroid dehydrogenases types 1, 2, and 3 catalyze bi-directional equilibrium reactions, rather than unidirectional metabolism, in HEK-293 cells. Arch. Biochem. Biophys. 429, 50-59.

Koh, E., Noda, T., Kanaya, J., Namiki, M., 2002. Differential expression of 17ßhydroxysteroid dehydrogenase isozyme genes in prostate cancer and noncancer tissues. Prostate 53, 154-159.

Komoto, J., Yamada, T., Watanabe, K., Takusagawa, F., 2004. Crystal structure of human prostaglandin F synthase (AKR1C3). Biochemistry 43, 2188-2198. 
17ß-HSD3 inhibition

Laplante, Y., Poirier, D., 2008. Proliferative effect of androst-4-ene-3,17-dione and its metabolites in the androgen-sensitive LNCaP cell line. Steroids 73, 266-271.

Le Lain, R., Barrell, K.J., Saeed, G.S., Nicholls, P.J., Simons, C., Kirby, A., Smith, H.J., 2002. Some coumarins and triphenylethene derivatives as inhibitors of human testes microsomal $17 \beta$-hydroxysteroid dehydrogenase (17 $\beta$-HSD type 3 ): further studies with tamoxifen on the rat testes microsomal enzyme. J. Enzyme Inhib. Med. Chem. 17, 93-100.

Lota, R.K., Dhanani, S., Owen, C.P., Ahmed, S., 2006. Synthesis, biochemical evaluation and rationalisation of the inhibitory activity of a series of 4hydroxyphenyl ketones as potential inhibitors of 17ß-hydroxysteroid dehydrogenase type 3 (17ß-HSD3). Bioorg. Med. Chem. Lett. 16, 4519-4522.

Lukacik, P., Kavanagh, K.L., Oppermann, U., 2006. Structure and function of human 17ß-hydroxysteroid dehydrogenases. Mol. Cell. Endocrinol. 248, 61-71.

Luu-The, V., Zhang, Y., Poirier, D., Labrie, F., 1995. Characteristics of human types 1, 2 and 3 17ß-hydroxysteroid dehydrogenase activities: oxidation/reduction and inhibition. J. Steroid Biochem. Mol. Biol. 55, 581-587.

Luu-The, V., Tremblay, P., Labrie, F., 2006. Characterization of type 12 17ßhydroxysteroid dehydrogenase, an isoform of type $317 \beta$-hydroxysteroid dehydrogenase responsible for estradiol formation in women. Mol. Endocrinol. $20,437-443$.

Luu-The, V., Belanger, A., Labrie, F., 2008. Androgen biosynthetic pathways in the human prostate. Best Pract. Res. Clin. Endocrinol. Metab. 22, 207-221.

Macdiarmid, F., Wang, D., Duncan, L.J., Purohit, A., Ghilchick, M.W., Reed, M.J., 1994. Stimulation of aromatase activity in breast fibroblasts by tumor necrosis factor alpha. Mol. Cell. Endocrinol. 106, 17-21. 
17 $\beta$-HSD3 inhibition

Maltais, R., Luu-The, V., Poirier, D., 2002. Synthesis and optimization of a new family of type $317 \beta$-hydroxysteroid dehydrogenase inhibitors by parallel liquidphase chemistry. J. Med. Chem. 45, 640-653.

Margiotti, K., Kim, E., Pearce, C.L., Spera, E., Novelli, G., Reichardt, J.K., 2002. Association of the G289S single nucleotide polymorphism in the HSD17B3 gene with prostate cancer in Italian men. Prostate 53, 65-68.

Mizokami, A., Koh, E., Fujita, H., Maeda, Y., Egawa, M., Koshida, K., Honma, S., Keller, E.T., Namiki, M., 2004. The adrenal androgen androstenediol is present in prostate cancer tissue after androgen deprivation therapy and activates mutated androgen receptor. Cancer Res. 64, 765-771.

Moon, Y.-A., Horton, J.D., 2003. Identification of two mammalian reductases involved in the two-carbon fatty acyl elongation cascade. J. Biol. Chem. 278, $7335-7343$.

Pelletier, G., Luu-The, V., Têtu, B., Labrie, F., 1999. Immunocytochemical localization of type $517 \beta$-hydroxysteroid dehydrogenase in human reproductive tissues. J. Histochem. Cytochem. 47, 731-737.

Peltoketo, H., Luu-The, V., Simard, J., Adamski, J., 1999. 17ß-Hydroxysteroid dehydrogenase (HSD)/17-ketosteroid reductase (KSR) family; nomenclature and main characteristics of the 17HSD/KSR enzymes. J. Mol. Endocrinol. 23, 1-11.

Penning, T.M., 1996. 17ß-Hydroxysteroid dehydrogenase inhibitors and inhibitor design. Endocr. Rel. Cancer 3, 41-56.

Penning, T.M., Burczynski, M.E., Jez, J.M., Hung, C.F., Lin, H.K., Ma, H., Moore, M., Palackal, N., Ratnam, K., 2000. Human 3 $\alpha$-hydroxysteroid dehydrogenase isoforms (AKR1C1-AKR1C4) of the aldo-keto reductase superfamily: functional 
17 $\beta$-HSD3 inhibition

plasticity and tissue distribution reveals roles in the inactivation and formation of male and female sex hormones. Biochem. J. 351, 67-77.

Pienta, K.J., Bradley, D., 2006. Mechanisms underlying the development of androgen-independent prostate cancer. Clin. Cancer Res. 12, 1665-1671.

Poirier, D., 2003. Inhibitors of 17ß-hydroxysteroid dehydrogenases. Curr. Med. Chem. 10, 453-477.

Rau, K.M., Kang, H.Y., Cha, T.L., Miller, S.A., Hung, M.C., 2005. The mechanisms and managements of hormone-therapy resistance in breast and prostate cancers. Endocr. Relat. Cancer 12, 511-532.

Shi, R., Lin, S.X., 2004. Cofactor hydrogen bonding onto the protein main chain is conserved in the short chain dehydrogenase / reductase family and contributes to nicotinamide orientation. J. Biol. Chem. 279, 16778-16785.

Stanway, S.J., Purohit, A., Woo, L.W., Sufi, S., Vigushin, D., Ward, R., Wilson, R.H., Stanczyk, F.Z., Dobbs, N., Kulinskaya, E., Elliott, M., Potter, B.V.L., Reed, M.J., Coombes, R.C., 2006. Phase I study of STX 64 (667 Coumate) in breast cancer patients: the first study of a steroid sulfatase inhibitor. Clin. Cancer Res. 12, 15851592.

Tchédam Ngatcha, B., Luu-The, V., Labrie, F., Poirier, D., 2005. Androsterone $3 \alpha-$ ether-3 $\beta$-substituted and androsterone $3 \beta$-substituted derivatives as inhibitors of type 3 17ß-hydroxysteroid dehydrogenase: Chemical synthesis and structureactivity relationship. J. Med. Chem. 48, 5257-5268.

Tindall, D.J., Rittmaster, R.S., 2008. The rationale for inhibiting 5alpha-reductase isoenzymes in the prevention and treatment of prostate cancer. J. Urol. 179, 12351242. 
17 $\beta$-HSD3 inhibition

Titus, M.A., Schell, M.J., Lih, F.B., Tomer, K.B., Mohler, J.L., 2005. Testosterone and dihydrotestesterone tissue levels in recurrent prostate cancer. Clin. Cancer Res. 11, 4653-4657.

Veldscholte, J., Berrevoets, C.A., Brinkmann, A.O., Grootegoed, J.A., Mulder, E., 1992. Anti-androgens and the mutated androgen receptor of LNCaP cells: differential effects on binding affinity, heat-shock protein interaction, and transcription activation. Biochemistry 31, 2393-2399.

Vicker, N., Day, J.M.,Bailey, H.V., Heaton, W., Gonzalez, A.M.R., Sharland, C.M., Reed, M.J., Purohit, A., Potter, B.V.L., 2007. Preparation of substituted aliphatic amines for use as anticancer or therapeutic agents inhibiting 17ß-hydroxysteroid dehydrogenase. WO 2007003934 A2.

Vihko, P., Herrala, A., Härkönen, P., Isomaa, V., Kaija, H., Kurkela, R., Pulkka, A., 2006. Control of cell proliferation by steroids: the role of 17HSDs. Mol. Cell. Endocrinol. 248, 141-148.

Yale, H.L.; Sowinski, F.; Spitzmiller, E.R., 1972. Novel Polycyclic Heterocycles. VIII. 6,11-dihydro-12H-dibenzo[b,f][1,4]thazocines and their derivatives. J. Heterocycl. Chem. 9, 899. 
17 $\beta$-HSD3 inhibition

\section{FIGURES}

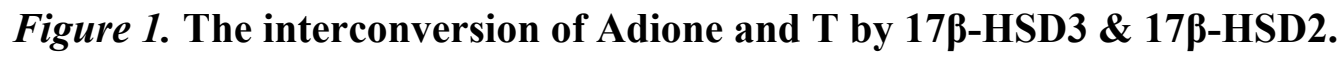

Figure 2. Expression and activity of 17及-HSD3 after cDNA transfection and selection of 293-EBNA cells. a. Expression of 17ß-HSD3 mRNA in 293-EBNA cells after transfection relative to 293-EBNAwt levels (transient $=48$ hours posttransfection; [HSD3] $\mathrm{pX}=$ no. of passages after selection of transfected cells for stable expression). b. Adione to $\mathrm{T}$ activity of the transfected cells 48 hours after transfection (2 hour assay in 24 well plates).

Figure 3. The structures and 17ß-HSD3 inhibitory activities of STX2171, STX2624 \& STX2622. $\left(\mathrm{IC}_{50}=\right.$ concentration at which the reaction is $50 \%$ inhibited).

Figure 4. LNCaP model development. a. Expression of steroidogenic enzyme mRNA in LNCaPwt cells (relative to the expression of 17 $\beta$-HSD1). b. Expression of 17ß-HSD3 mRNA in LNCaP[HSD3] cells in comparison to LNCaPwt, 293-EBNAwt and 293-EBNA[HSD3] cells. c. Adione to T activity of LNCaPwt and LNCaP[HSD3] cells in comparison to 293-EBNAwt and 293-EBNA[HSD3] cells. d. Stimulation of LNCaPwt cell proliferation over 14 days $(\mathrm{A}=$ Adione; $\mathrm{OH}-\mathrm{F}=$ hydroxyflutamide; $\%$ $=\%$ of non-stimulated growth in $0.1 \%$ FBS-containing medium). e. Stimulation of LNCaP[HSD3] cell proliferation over 15 days $(\mathrm{A}=$ Adione; $\mathrm{OH}-\mathrm{F}=$ hydroxyflutamide; $\%=\%$ of non-stimulated growth in $0.1 \%$ FBS-containing medium). 
17 $\beta$-HSD3 inhibition

Figure 5. Inhibition of Adione-stimulated proliferation of LNCaP[HSD3] and

LNCaPwt cells in vitro. a. The effect of $5 \mu \mathrm{M}$ of the 17 $\beta$-HSD3 inhibitors, STX2171, STX2624 and STX2622, on proliferation of LNCaP[HSD3] cells stimulated by $10 \mathrm{nM}$ Adione $(\mathrm{A})$. $(\mathrm{OH}-\mathrm{F}=$ hydroxyflutamide) b. The effect of STX2171 at 500nM and STX2624 at both $500 \mathrm{nM}$ and $5 \mu \mathrm{M}$ on proliferation of LNCaP[HSD3] cells stimulated by $10 \mathrm{nM}$ Adione. c. The effect of $500 \mathrm{nM}$ STX2171 on the stimulation of LNCaPwt cells by $10 \mathrm{nM}$ Adione (A), T or DHT, or $1 \mu \mathrm{M}$ hydroxyflutamide (OH-F).

Figure 6. The effect of STX2171 on Adione-stimulated growth of LNCaPwt xenografts in vivo. LNCaPwt tumour growth in castrated male MF-1 nude mice was stimulated using $100 \mu \mathrm{g}$ Adione (s.c.) / day. When tumours became visible the mice were dosed additionally with $25 \mathrm{mg} / \mathrm{kg} /$ day (s.c.) STX2171 or with vehicle (5\% THF / 95\% PG). Tumour volume = percent of volume at start of STX2171 dosing; bars = s.d.; STX2171 vs vehicle-treated at day $14,{ }^{*} \mathrm{p}<0.05$ (Student's $t$-test). 
Day et al., 2008. Figure 1. The interconversion of Adione and T by 17 $\beta$-HSD3 \& 17 $\beta$ HSD2.
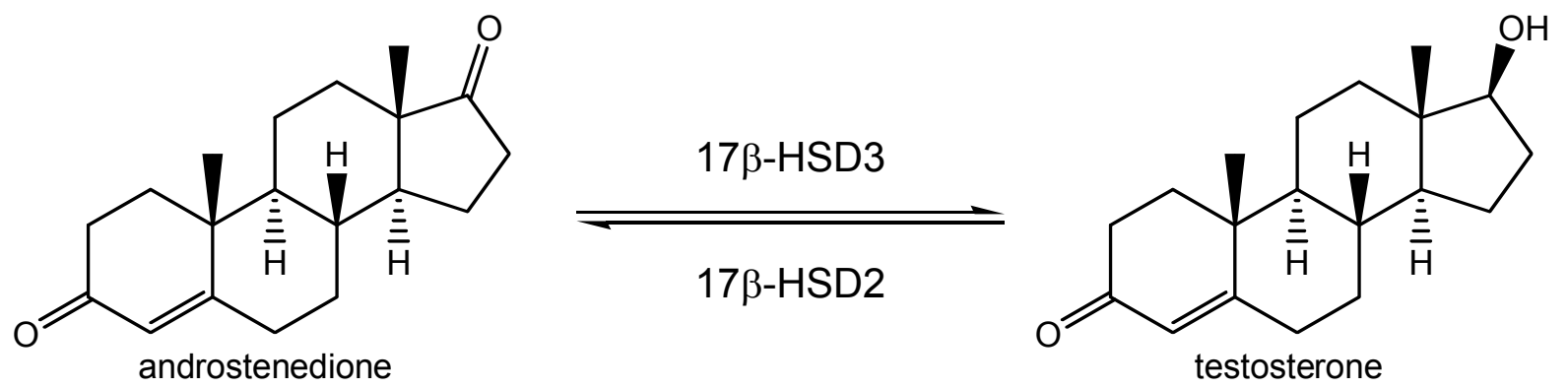
Day et al., 2008. Figure 2. Expression and activity of 17 $\beta$-HSD3 after cDNA transfection and selection of 293-EBNA cells. a. Expression of 17ß-HSD3 mRNA in 293-EBNA cells after transfection relative to 293-EBNAwt levels (transient $=48$ hours post-transfection; [HSD3] pX = no. of passages after selection of transfected cells for stable expression). b. Adione to T activity of the transfected cells 48 hours after transfection ( 2 hour assay in 24 well plates).

a.

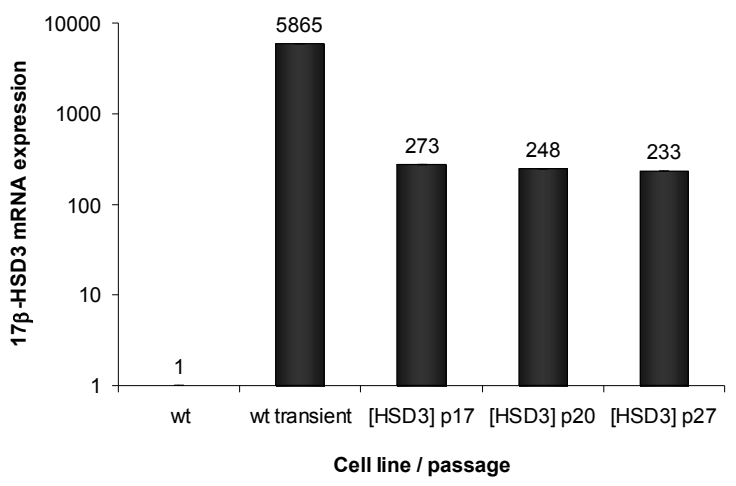

b.

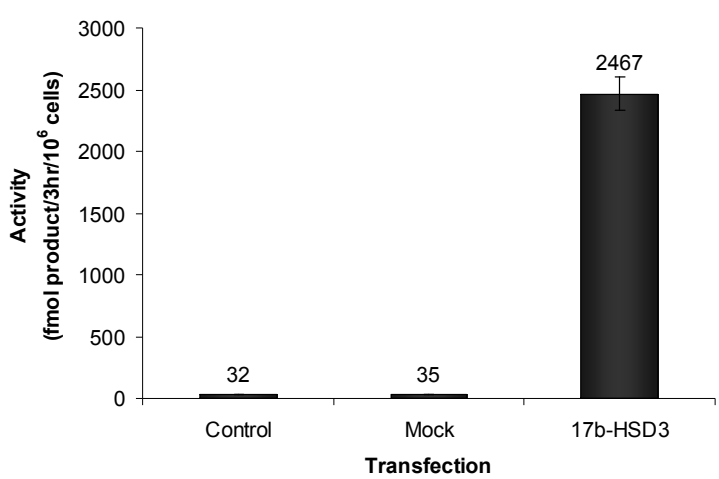


Day et al., 2008. Figure 3 . The structures and 17 $\beta$-HSD3 inhibitory activities of STX2171, STX2624 \& STX2622.
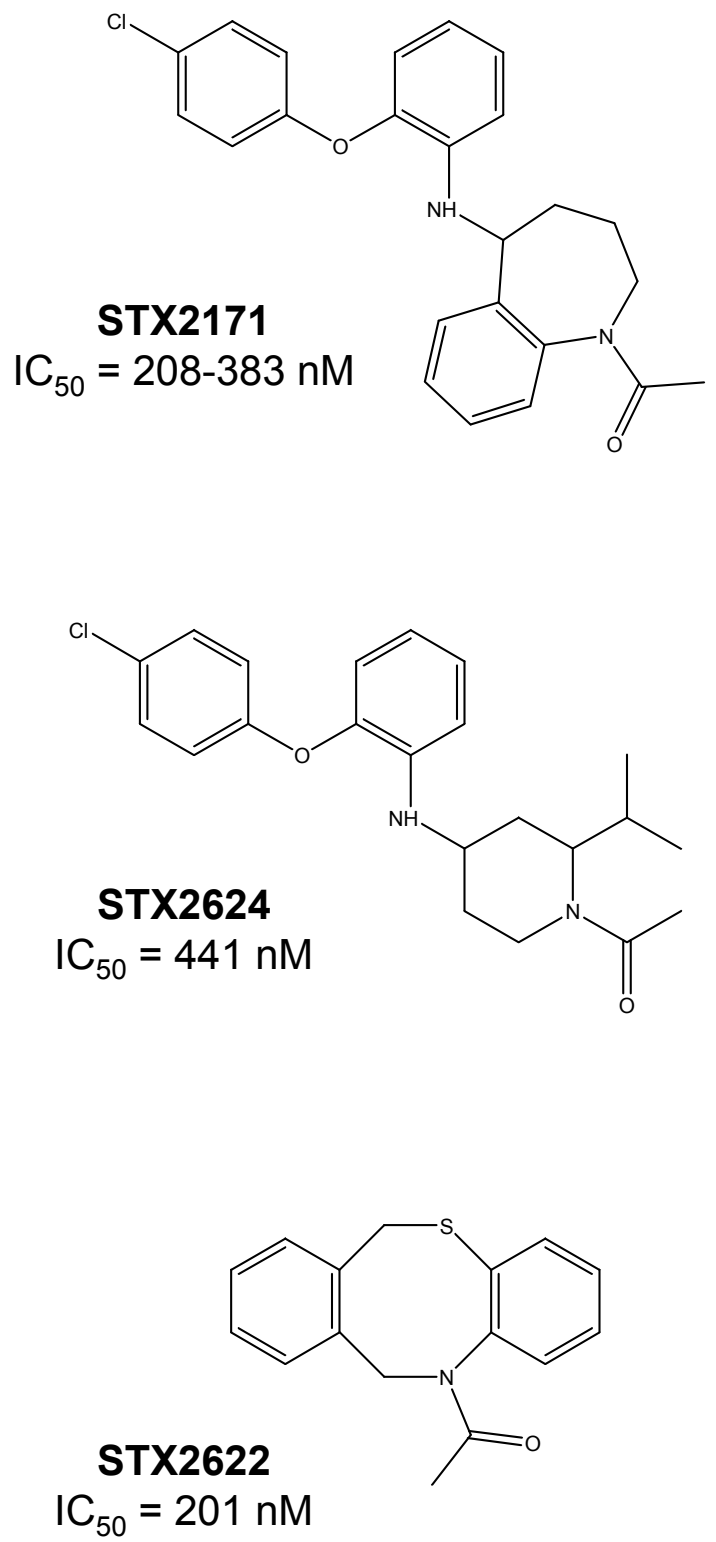
Day et al., 2008. Figure 4. LNCaP model development. a. Expression of steroidogenic enzyme mRNA in LNCaPwt cells (relative to the expression of 17 $\beta$-HSD1). b. Expression of 17ß-HSD3 mRNA in LNCaP[HSD3] cells in comparison to LNCaPwt, 293-EBNAwt and 293-EBNA[HSD3] cells. c. Adione to T activity of LNCaPwt and LNCaP[HSD3] cells in comparison to 293-EBNAwt and 293-EBNA[HSD3] cells. d. Stimulation of LNCaPwt cell proliferation over 14 days $(\mathrm{A}=$ Adione; $\mathrm{OH}-\mathrm{F}=$ hydroxyflutamide; $\%=\%$ of nonstimulated growth in $0.1 \%$ FBS-containing medium). e. Stimulation of LNCaP[HSD3] cell proliferation over 15 days $(\mathrm{A}=$ Adione; $\mathrm{OH}-\mathrm{F}=$ hydroxyflutamide; $\%=\%$ of nonstimulated growth in $0.1 \%$ FBS-containing medium).

a.

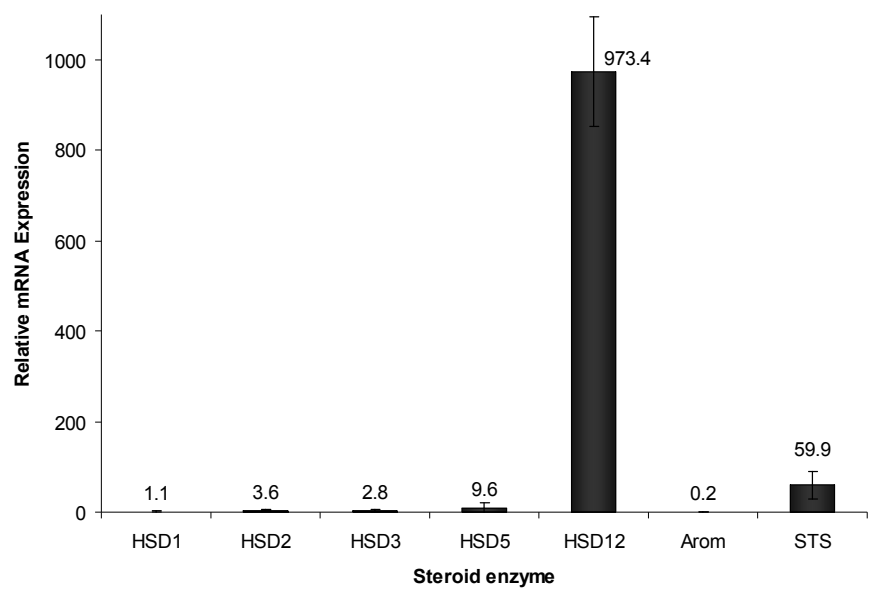

b.

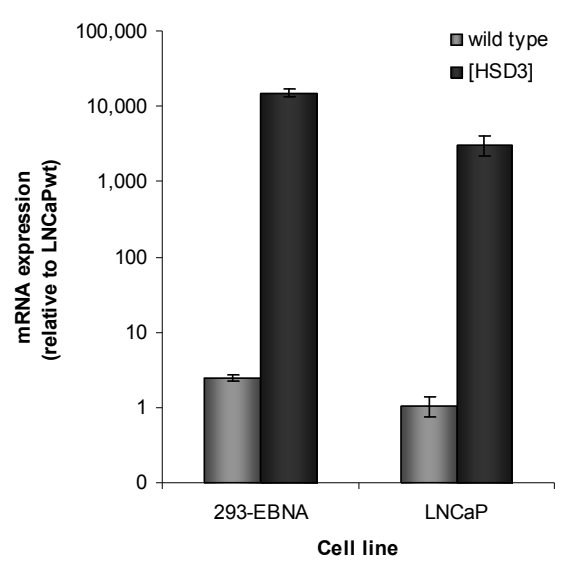

d.

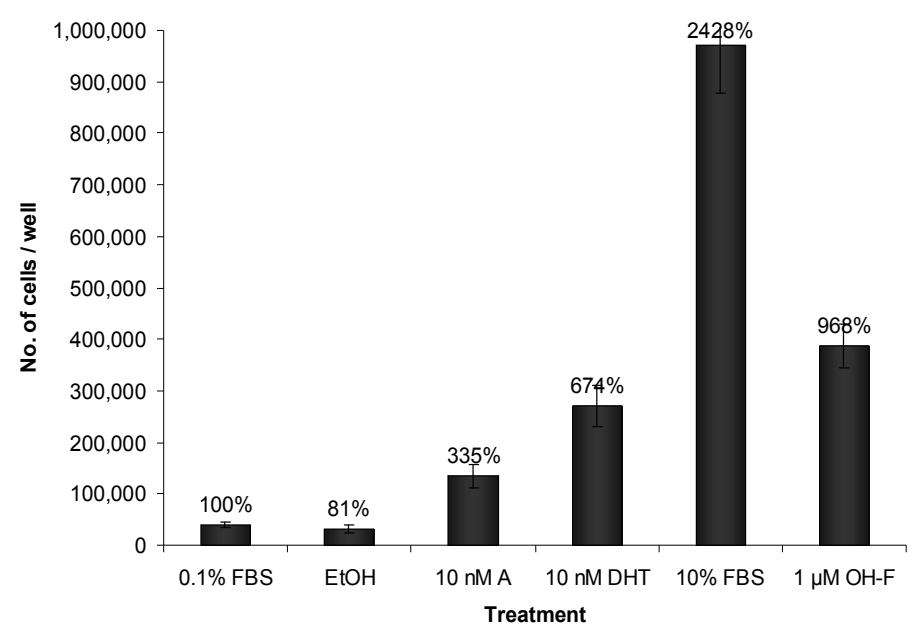

c.

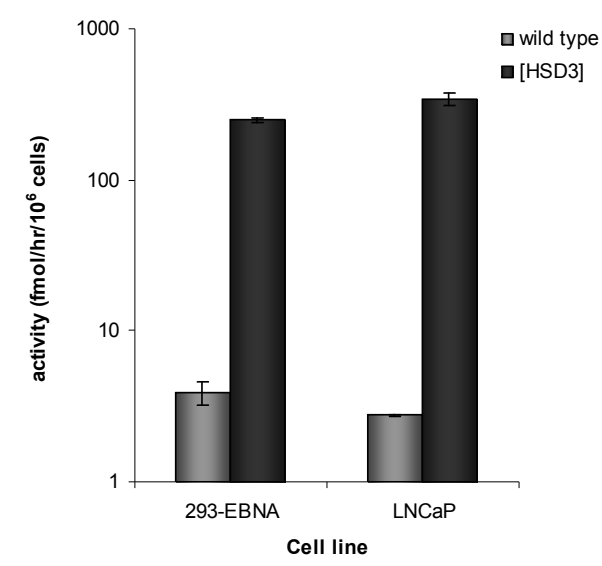

e.

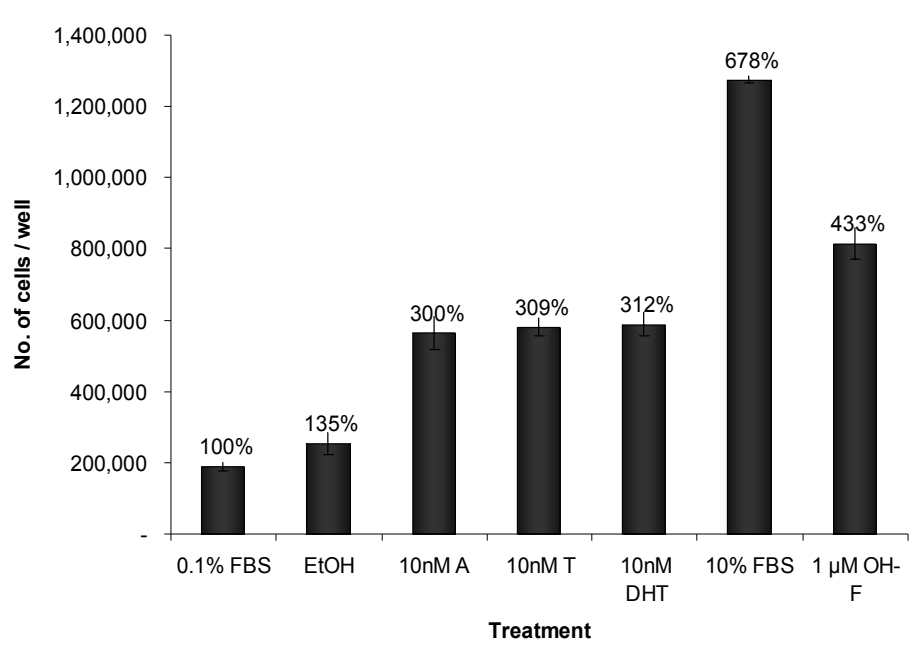


Day et al., 2008. Figure 5. Inhibition of Adione-stimulated proliferation of LNCaP[HSD3] and LNCaPwt cells in vitro. a. The effect of $5 \mu \mathrm{M}$ of the 17ß-HSD3 inhibitors, STX2171, STX2624 and STX2622, on proliferation of LNCaP[HSD3] cells stimulated by $10 \mathrm{nM}$ Adione (A). (OH-F = hydroxyflutamide) $\mathbf{b}$. The effect of STX2171 at $500 \mathrm{nM}$ and STX2624 at both $500 \mathrm{nM}$ and $5 \mu \mathrm{M}$ on proliferation of LNCaP[HSD3] cells stimulated by $10 \mathrm{nM}$ Adione. c. The effect of $500 \mathrm{nM}$ STX2171 on the stimulation of LNCaPwt cells by $10 \mathrm{nM}$ Adione (A), T or DHT, or $1 \mu \mathrm{M}$ hydroxyflutamide $(\mathrm{OH}-\mathrm{F})$.

a.

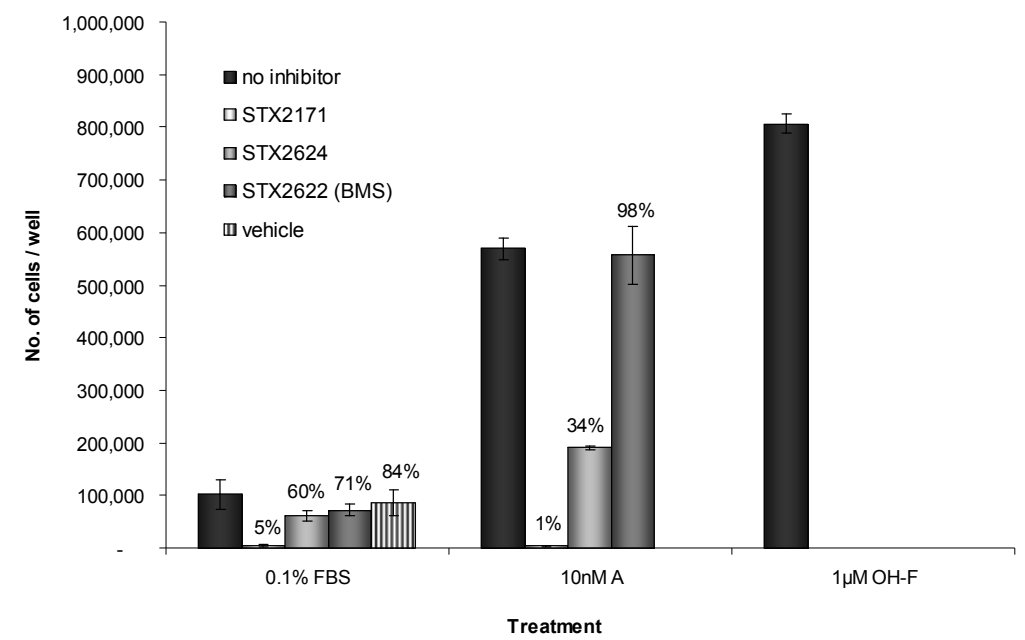

b.

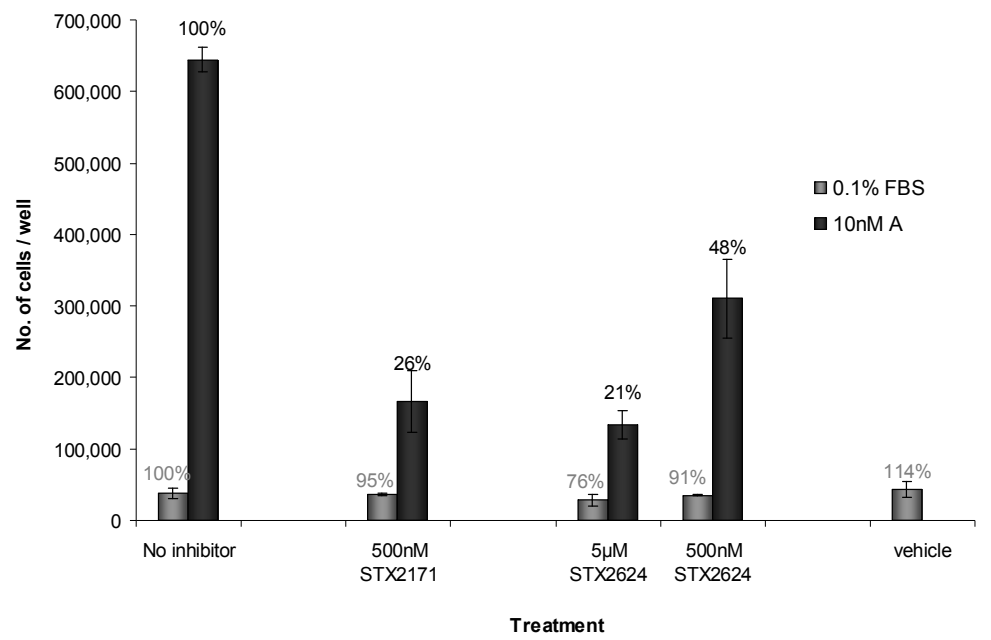

C.

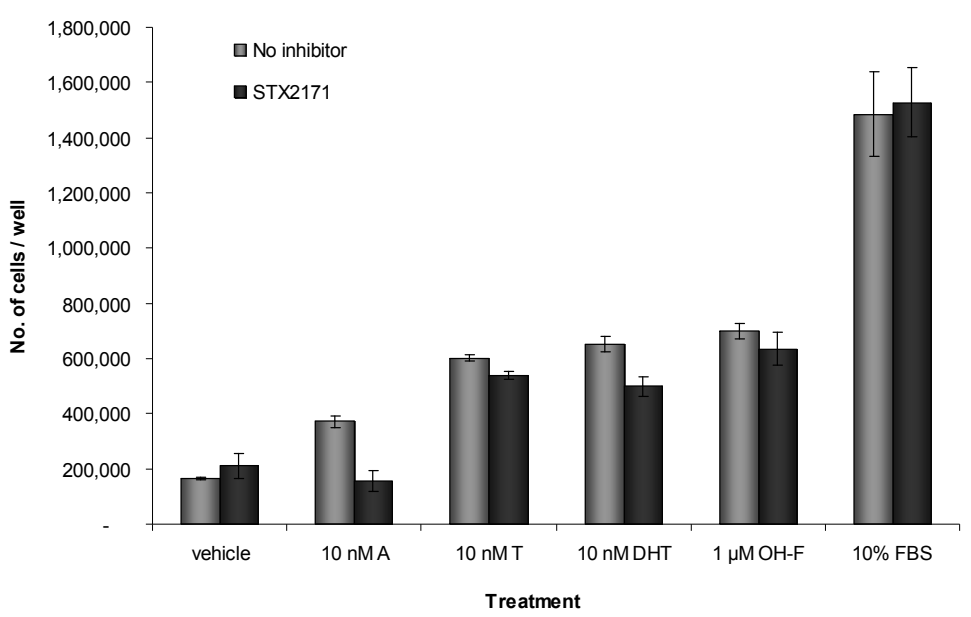


Day et al., 2008. Figure 6. The effect of STX2171 on Adione-stimulated growth of LNCaPwt xenografts in vivo. LNCaPwt tumour growth in castrated male MF-1 nude mice was stimulated using $100 \mu \mathrm{g}$ Adione (s.c.) / day. When tumours became visible the mice were dosed additionally with $25 \mathrm{mg} / \mathrm{kg} /$ day (s.c.) STX2171 or with vehicle (5\% THF / $95 \%$ PG). Tumour volume = percent of volume at start of STX2171 dosing; bars = s.d.; STX2171 vs vehicle-treated at day $14,{ }^{*} p<0.05$ (Student's $t$-test).

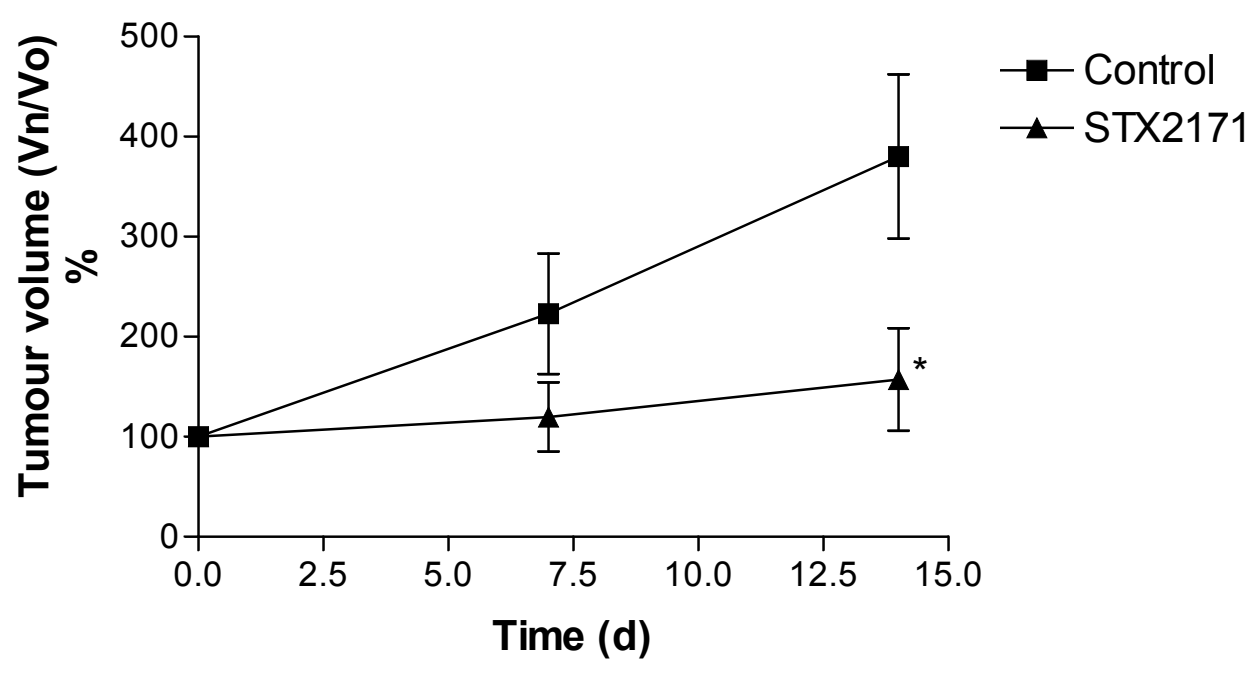

